\title{
Manajemen Strategik Bimbingan Manasik Haji dalam Meningkatkan Kualitas Jemaah
}

\author{
Ni'mah Nurfadillah ${ }^{1 *}$, Ahmad Sarbini $1^{1}$, Herman $2^{2}$ \\ 123Jurusan Manajemen Dakwah, Fakultas Dakwah dan Komunikasi, UIN Sunan Gunung Djati, \\ Bandung \\ *Email:1154030057@student.uinsgd.ac.id
}

\begin{abstract}
ABSTRAK
Penelitian ini bertujuan untuk mengetahui manajemen strategik Bimbingan Manasik Haji KBIH Masjid Raya Bandung melalui tahapan perumusan strategi, pelaksanaan strategi dan evaluasi strategi untuk meningkatkan kualitas jemaah calon haji. Agar didapatkan data yang valid penelitian ini menggunakan metode deskriptif dengan teknik pengumpulan data wawancara, observasi, dan analisis dokumen. Hasil penelitian menunjukkan bahwa manajemen strategik bimbingan manasik haji di KBIH Masjid Raya Bandung yaitu melakukan pengembangan visi, misi dan tujuan untuk menjadikan jemaah haji yang mandiri, dengan melakukan Bimsik Haji yang memfokuskan terhadap teori dan praktik. Pada pelaksanaan strategi, bimsik dilakukan semaksimal mungkin oleh para pembimbing yang ahli di bidangnya. Prosedur yang dijalankan oleh $\mathrm{KBIH}$ Masjid Raya Bandung dimulai dari pendaftaran sampai dengan pelaksanaan ibadah haji (bimbingan di tanah air, di Arab Saudi dan pasca ibadah haji yang dikumpulkan melalui wadah Jamiatul Hujjaj). Tahapan manajemen strategik dilakukan untuk membantu KBIH menjadikan jemaah haji berkualitas.
\end{abstract}

Kata Kunci: Manajemen; Strategik; Manasik; Kualitas; Jemaah.

\section{ABSTRACT}

This study aims to determine the strategic management of the Haij Ritual Guidanceby KBIH Bandung Great Mosque through the stages of strategy formulation, strategy implementation and strategy evaluation to enbance the quality of prospective pilgrims. In order to obtain a valid data, this study uses descriptive methods with interview, observation and document analysistechniques for collecting the data. The results shows that the strategic management of Haij Ritual Guidance in KBIH Masjid Raya Bandung is to develop a vision, mission and goals to make an independent pilgrims, by conducting Haij Ritual Guidancethat focuses on theory and practice. In the implementation of the strategy, Haij Ritual Guidance carried out as much as possible by the supervisors who are experts in their fields. The procedure that is 
carried out by the KBIH Bandung Great Mosque starts from registration to the implementation of the pilgrimage (guidance in the homeland, in Saudi Arabia and after the pilgrimage collected through the Jamiatul Hujjajorganisation). The stages of strategic management are carried out to help KBIH make qualified pilgrims.

Keywords : Management; Strategic; Manasik; Quality; Pilgrims.

\section{PENDAHULUAN}

Ibadah haji merupakan ibadah yang kompleks dengan segala runtutan kegiatan yang ada di dalamnya, di sisi lain kegiatan ibadah haji merupakan rukun islam ke5 yang wajib dilakukan oleh umat islam yang mampu menunaikannya baik secara fisik ataupun materi dan wajib bagi orang yang melakukan nazar, adapun yang telah melaksanakan ibadah haji hukumnnya menjadi sunat (Dirjen Penyelenggaraan Ibadah Haji dan Umrah, 2017: 3). Haji menurut bahasa yaitu berniat pergi, bermaksud atau menuju ke suatu tempat tertentu (Sukayat, 2016: 4). Menurut Fahruddin dalam Sukayat (2016: 4) haji adalah sengaja berkunjung menziarahi ka'bah yang terletak di Masjidil Haram di Makkah, dengan niat menunaikan ibadah haji, yaitu rukun islam yang kelima guna memenuhi perintah Allah.

Dalam pelaksanaan ibadah haji Pemerintah RI dan Kelompok Bimbingan Ibadah Haji (KBIH) bermitra untuk membantu masyarakat yang akan melaksanakan ibadah haji yaitu dengan mengadakan kegiatan Bimbingan Manasik Haji. KBIH itu sendiri merupakan lembaga jasa yang didirikan masyarakat yang keberadaannya telah mendapatkan izin operasional dari pemerintah. Manasik Haji merupakan aktivitas peragaan atau replika ibadah haji yang telah disesuaikan dengan rukun, wajib dan sunah haji. Dalam Sukayat (2016: 1) manasik haji diartikan sebagai hal-hal yang berkaitan dengan ibadah haji, seperti ihram, tawaf, sa'i, wukuf serta segala peragaan ibadah haji yang disamakan dengan rukun-rukunnya. Bimbingan manasik haji yang dilakukan $\mathrm{KBIH}$ bertujuan untuk memberikan bekal dan pengetahuan bagi jemaah bukan hanya tentang manasik dan proses ibadah haji tetapi juga menyangkut akhlakul karimah, dan mempelajari budaya Arab Saudi (Dirjen Penyelenggaraan Ibadah Haji dan Umrah, 2017: 13).

Selanjutnya untuk menjadikan pelaksanaan ibadah haji yang aman, tentram dan khidmat maka manajemen strategik dibutuhkan KBIH untuk menyusun dan mengatur kegiatan bimbingan manasik haji. Manajemen strategik merupakan serangkaian keputusan dan tindakan mendasar yang dibuat oleh manajemen puncak yang diimplementasikan oleh unsur yang ada dalam organisasi untuk mencapai tujuan organisasi (Siagian, 2000: 15). Menurut Fred R. David dalam Taufiqurokhman (2016: 17-18) manajemen strategik memiliki sebuah rangkain mengenai kebijakan, dan langkah-langkah yang akan diambil sebagai penentu kinerja organisasi dalam jangka panjang, hal tersbeut dilalui dalam tahapan 
manajemen startegik yaitu perumusan strategi, pelaksanaan strategi dan evaluasi strategi. Manajemen strategik perlu diterapkan oleh KBIH yang diharapkan dapat bermanfaat untuk meningkatkan kualitas jemaah. Maka dari itu KBIH Masjid Raya Bandung yang merupakan lembaga dibawah naungan Masjid Raya Bandung yang tergolong aktif memberangkatkan jemaah calon haji setiap tahun dengan kegiatan bimbingan manasik haji yang berfokus kepada teori dan praktik menjadi objek penelitian untuk mengetahui bagaimana manajemen strategik yang dijalankan oleh para pengurus KBIH.

Pembahasan mengenai manajemen strategik dan bimbingan manasik haji juga telah banyak dibahas, seperti dalam skripsi Asep Kurniawan (2016) dengan judul Manajemen Strategik Pondok Pesantren dalam Menyiapkan Kader Da’i yang Berkualitas (Studi Deskriptif di Pondok Pesantren Terpadu Darusyifa AlFithroh Perguruan YASPIDA Sukabumi Jawa Barat) yang menyatakan bahwasannya keputusan strategi pondok pesantren untuk mendukung pertumbuhan yang agresif dihasilkan dari tahapan manajemen strategik. Kemudian penelirian yang dilakukan oleh Siti Bilqis Adawiyah (2016) dengan judul skripsi Strategi Pengorganisasian Bimbingan Manasik Haji di LHM Muhammadiyah Jawa Barat, untuk meningkatkan kualitas jemaah haji dalam bimbingan manasik haji dilakukan dengan strategi pengorganisasian melalui unsur-unsur pengorganisasian. Adapun letak perbedaaan penelitian ini dengan sebelumnya yaitu dalam fokus penelitiannya. Penelitian yang dilakukan di $\mathrm{KBIH}$ Masjid Raya Bandung ini membahas mengenai bagaimana manajamemen strategik dilakukan pada sebuah program bimbingan manasik haji bukan lembaga seperti pada penelitian sebelumnya. Dalam penelitian ini memfokuskan kepada tahapan manajemen strategik menurut teori Fred R. David yaitu perumusan strategi, pelaksanaan strategi dan evaluasi strategi.

KBIH Masjid Raya Bandung terletak di Jl. Dalem Kaum No. 14 RT. 03, RW.01 Kel. Balonggede Kec. Regol Bandung, Jawa Barat. KBIH Masjid Raya Bandung telah berdiri sejak tahun 2001 dan ditetapkan pada tanggal 28 Mei 2002 dengan SK Nomor: Mi-14/1,Hj.09/1170/2002. Seperti yang telah disebutkan sebelumnya bahwasannya KBIH ini berada dibawah naungan Masjid Provinsi Jawa Barat yairu Masjid Raya Bandung yang berada di alun-alun Kota Bandung, yang merupakan titik paling strategis bagi para pengunjung maupun wisatawan yang datang dari berbagai daerah.

Berdasarkan latar belakang masalah yang telah dipaparkan maka penelitian ini memiliki fokus penelitian terhadap manajemen strategik yang dilakukan dalam program bimbingan manasik haji dalam memberikan materi yang optimal oleh KBIH Masjid Raya Bandung, melalui pertanyaan peneltian yaitu; (1) bagaimana perumusan strategi bimbingan manasik haji dalam meningkatkan kualitas jemaah di KBIH Masjid Raya Bandung? (2) bagaimana pelaksanaan strategi bimbingan manasik haji dalam meningkatkan kualitas jemaah di $\mathrm{KBIH}$ 
Masjid Raya Bandung? (3) bagaimana evaluasi strategi bimbingan manasik haji dalam meningkatkan kualitas jemaah di KBIH Masjid Raya Bandung?

Metode yang dilakukan dalam penelitian ini yaitu metode deskriptif. Dalam Nazir (2011: 54) dijelaskan bahwa metode deskriptif merupakan suatu metode dalam meneliti status sekelompok manusia, suatu objek, suatu set kondisi, suatu sistem pemikiran, ataupun suatu kelas peristiwa pada masa sekarang. Pengaplikasian metode ini tertuju kepada fenomena tertentu di KBIH Masjid Raya Bandung untuk digambarkan dan dijelaskan secara mendalam dan faktual dengan menyusun data, menganalisis data melalui wawancara, observasi dan studi kepustakaan yang menyeluruh kepada objek penelitian, dalam hal ini mengenai Manajemen Strategik Bimbingan Manasik Haji dalam Meningkatkan Kualitas Jamaah di KBIH Masjid Raya Bandung. Dengan menggunakan metode tersebut diharapkan bisa menghasilkan data yang akurat, faktual, dan lengkap berdasarkan hasil dari pengumpulan dan pengolahan data secara sistematis.

\section{LANDASAN TEORITIS}

Teori yang menjadi landasan dalam penelitian ini yaitu teori manajemen strategik dan beberapa pembahasan mengenai bimbingan manasik haji, dan kualitas jemaah. Manajemen strategik merupakan gabungan dari kata manajemen dan strategik. Terry \& Rue (2000: 1) dalam bukunya menjelaskan bahwa manajemen merupakan suatu proses atau kerangka kerja yang melibatkan bimbingan atau pengarahan suatu kelompok orang-orang kearah tujuan-tujuan organisasional atau maksud-maksud yang nyata. Sedangkan strategi yaitu suatu penentuan sasaran dan tujuan dasar jangka panjang dari suatu organisasi (perusahaan) serta pengadopsian seperangkat tindakan serta alokasi sumber-sumber yang perlu untuk mencapai sasaran-sasaran tersebut (Taufiqurokhman, 2016: 12). Manajemen strategik apabila dikaitkan dengan terminologi manajemen yaitu sebuah proses perencanaan, pengarahan (directing) pengorganisasian dan pengendalian berbagai keputusan dan tindakan strategis perusahaan dengan tujuan untuk mencapai keunggulan kompetitif bagi perusahaan (Solihin, 2012: 67). Manajemen strategik merupakan keputusan-keputusan dan tindakan perusahaan yang sangat menentukan berjalannya perusahaan dalam jangka waktu panjang. Keputusan-keputusannya berdimensi luas, berdampak menyeluruh terhadap perusahaan (Amir, 2011: 18). Berjalannnya proses manajemen strategik bukan hanya oleh manajemen puncak, tetapi dibutuhkan juga kerja sama semua komponen yang ada dalam organisasi.

Fred R. David dalam (Taufiqurokhman, 2016: 15) Mendefinisikan manajemen strategik sebagai ilmu mengenai perumusan, pelaksanaan dan evaluasi keputusan-keputusan lintas fungsi yang memungkinkan organisasi mencapai tujuannya. Jadi Manajemen strategik merupakan kegiatan manajemen mencakup sekumpulan strategi untuk membantu perusahaan dalam mencapai 
sasaran melalui tahapan, perumusan, pelaksanaan dan evaluasi.

Perumusan strategi merupakan suatu proses yang berorientasi pada hasil yang ingin dicapai selama kurun waktu 1 (satu) tahun sampai dengan 5 (lima) tahun secara sistematis dan berkesinambungan dengan memperhitungkan potensi, peluang dan kendala yang ada atau yang mungkin timbul (Kadmasasmita, 2005: 21). Tahap perumusan strategi meliputi pengembangan misi usaha, mengidentifikasikan sebuah peluang dan ancaman dari eksternal, mengukur serta mentetapkan kelemahan maupun kekuatan internal perusahaan, menetapkan sasaran jangka panjang, menimbang alternatif lain, dan memilih strategi khusus yang akan diterapkan pada kasus-kasur tertentu (Taufiqurokhman, 2016: 31).

Perumusan visi misi dan tujuan perusahaan secara bersamaan akan menghasilkan pilihan strategi-strategi yang akan digunakan, dengan acuan agar tercapainya tujuan-tujuan perusahaan. Kemudian analisis lingkunagan dalam sebuah perusahaan dikategorikan menjadi dua yaitu lingkungan eksternal dan lingkungan internal perusahaan. Menurut Duncan dalam Solihin (2012: 105), yang dimaksud dengan lingkungan eksternal perusahaan adalah berbagai faktor yang berada diluar organisasi yang harus diperhitungkan saat membuat keputusan. Sedangkan lingkungan internal lebih pada analisa intern perusahaan dalam rangka menilai atau mengidentifikasi kekuatan dan kelemahan dari tiaptiap divisi antara lain; divisi keuangan, pemasaran, $\mathrm{R} \& \mathrm{D}$, personil dan MIS (Wahyudi, 1996: 49). Selanjutnya dalam kegiatan analisis eksternal, sebuah perusahaan mengidentifikasi dan menelaah lebih mendalam mengenai peluang (Opportunity) yang berkembang pada masa itu serta ancaman (Threat) dari para pesaing perusahaan yang mungkin ada. Sedangkan dalam analisis internal lebih fokus terhadap kekuatan (Strength) dan kelemahan (Weakness) yang dimiliki perusahaan. Dengan penggunaan analisis tersebut maka perusahaan dikenal dengan malakukan analisis SWOT (Wahyudi, 1996: 50).

Pelaksanaan strategi yaitu kegiatan-kegiatan manajemen yang berkaitan dengan keputusan dari hasil strategi yang dipilih, pengevaluasian hasil kinerja melalui kegiatan perbaikan dan koreksi. Sebuah strategi perlu dieksekusi secara efektif dan efisien (Hartono, 2005: 76). Adapun ketiga hal mendasar yang menjadikan adanya sebuah kegiatan pelaksanaan strategi dalam manajemen strategik yaitu pada program kerja, prosedur dan pengorganisasian. Program kerja dapat diartikan sebagai rencana kegiatan yang akan dilakukan oleh organisasi atau lembaga dalam waktu tertentu yang keberadaannya berdasarkan dari kesepakatan para anggota didalamnya.

Selanjutnya yaitu prosedur menurut Mulyadi (1993: 5) ialah urutan klerikal biasanya melibatkan beberapa orang dalam suatu departemen atau lebih, yang dibuat untuk menjamin penanganan secara seragam transaksi perusahaan yang terjadi berulang-ulang. Berdasarkan pengertian tersebut dapat dipahami bahwa 
prosedur merupakan serangkaian kegiatan yang berhubungan dengan beberapa orang, guna menangani segala bentuk transaksi perusahaan yang sifatnya berkesinambungan. Adapun pengorganisasian adalah sistem kerjasama kelompok orang, yang dilakukan dengan pembidangan dan pembagian seluruh pekerjaan/tugas dengan membentuk sejumlah satuan atau unit kerja, yang menghimpun pekerjaan sejenis dalam satu satuan atau unit kerja (Nawawi, 2005: 63-64).

Tahapan terakhir dalam manajemen strategik yaitu Evaluasi Strategi. Evaluasi Strategi, merupakan proses untuk mendapatkan informasi perihal rencana-rencana bisnis serta kemampuannya dan juga melakukan perbandingan apakah informasi tersebut telah sesuai dengan standar yang telah ditentukan atau tidak (Wahyudi, 1996: 139). Jadi evaluasi strategi berguna untuk meneliti apa yang salah dalam kegiatan manajemen strategi untuk diperbaiki sebagai bekal di masa yang akan datang agar perusahaan bisa menjadi lebih baik lagi. Dalam hal ini yaitu evaluasi strategik dalam kegiatan bimbingan manasik haji yang dilakukan oleh KBIH.

Bimbingan Manasik Haji dilakukan berdasarkan kebutuhan masyarakat yang ingin menunaikan ibadah haji. Haji dilihar dari sudut bahasa yaitu berniat pergi, atau bermaksud untuk pergi ke tempat tertentu. Dalam Sukayat (2016: 4), haji menurut syara' adalah menyengaja untuk berkunjung ke Makkah (ka'bah) untuk memenuhi perintah Allah serta menghadapi keridaan-Nya.dengan melaksanakan ibadah yang terdiri atas tawaf, sai, wukuf dan ibadah-ibadah lain. Kegiatan ibadah haji ini dimulai pada akhir tahun ke-9 hijriah sesudah Rasulullah SAW. Waktu pelaksanaan ibadah haji, menurut (Sukayat, 2016: 10) yaitu pada bulan Syawwal sampai sepuluh hari pertama Dzulhijjah, dan pelaksanaan ibadah intinya yaitu tanggal 8-13 Dzulhijjah namun waktu secara keseluruhan ibadahnya yaitu pada bulan Syawwal, Dzulqa'dah, dan 13 hari pertama bulan Dzulhijjah disetiap tahunnya.

Menurut Taufiqurrochman (2011: 20) pelaksanaan manasik haji terbagi menjadi tiga. Yaitu baji tamattu, haji ifrad dan haji qiran. Haji tamattu, haji dengan cara ini yaitu dengan mengerjakan umrah terlebih dahulu, baru mengerjakan haji. Dengan cara ini jemaah wajib membayar dam/denda. Haji ifrad, yaitu mengerjakan haji saja. Cara ini tidak wajib membayar dam, pelaksanaan haji dengan cara Ifrad ini dapat dipilih oleh jemaah yang kedatangaannya mendekati waktu wukuf kurang lebih 5 (lima) hari sebelum wukuf. Haji qiran, yaitu mengerjakan haji dan umrah di dalam satu niat dan satu pekerjaan sekaligus. Cara ini wajib membayar Dam dan Nusuk (sesuai dengan ketentuan syariah). Manasik haji dilakukan untuk memberikan bekal kepada para calon jemaah haji ketika akan melaksanakan ibadah haji. Pembekalan tersebut bukan hanya berbentuk materi tetapi juga praktik di lapangan. Landasan hukum melaksanakan ibadah haji terdapat dalam Al-Qur'an salah satunya dalam Q.S Al-Imran ayat 97. 
Mengenai ibadah haji DPR RI mengeluarkan Undang-Undang sebagai landasan hukum yang mengatur mengenai penyelenggaraan Ibadah Haji dan Umrah. Undang-Undang (UU) Nomor 8 Tahun 2019 yang merupakan Undang-Undang Pengganti UU Nomor 13 Tahun 2008 tentang Penyelenggaraan Ibadah Haji dan Umrah. Penyelenggaraan ibadah haji juga diatur dalam Keputusan Menteri Agama Nomor 224 Tahun 1999 yang kemudian disempurnakan lagi dengan Nomor 371 Tahun 2002 tentang Penyelenggaraan Ibadah Haji dan Umrah, adalah sebagai hasil penyempurnaan Dasar Hukum dan Sistem Penyelenggaraan Ibadah Haji di Indonesia.

Membahas mengenai KBIH dalam Siswanto (2006: 31) dipaparkan bahwa Kelompok Bimbingan Ibadah Haji (KBIH) merupakan lembaga yang dibentuk oleh kelompok masyarakat tertentu dengan tujuan untuk membantu/ membimbing calon haji sejak dari manasik, pelaksanaan ibadah haji sampai kembali di tanah air. Dalam Undang-Undang Nomor 8 Tahun 2019 diterangkan bahwasannya Kelompok Bimbingan Ibadah Haji dan Umrah yang selanjutnya disingkat KBIHU adalah kelompok yang menyelenggarakan bimbingan Ibadah Haji dan Ibadah Umrah yang telah mendapatkan izin dari Menteri. Dari pengertian diatas dapat diambil kesimpulan bahwa KBIH merupakan lembaga yang didirikan oleh masyarakat untuk mewadahi segala aktivitas pembimbingan ibadah haji dan keberadaannya telah diakui oleh Pemerintah.

Peran KBIH sampai saat ini amat dibutuhkan baik oleh para jemaah maupun Kementrian Agama. Bagi jemaah akan membantu memberikan ketenangan batin karena kegiatan pembimbingan ibadah haji telah dilakukan dari sebelum berangkat haji sampai nanti ketika berada di tanah suci. Bagi Kementrian Agama fungsi dan peran KBIH yaitu sebagai mitra kerja yang dapat membantu tugas dan kewajiban pembimbingan calon jemaah haji.

Pelaksanaan bimbingan manasik haji ini bertujuan untuk menjadikan jemaah yang berkualitas. Menurut Deming kualitas adalah kesesuaian dengan kebutuhan pasar. Maksudnya kualitas sebagai kesesuaian dengan kebutuhan pasar atau konsumen sebuah perusahaan harus benar-benar dapat memahami apa yang dibutuhkan konsumen atau suatu produk yang akan dihasilkan (https://eprints.ums.ac.id diunduh pada hari Senin Tangal 1 Juli 2019 pukul 11.31). Kualitas merupakan indikator yang penting bagi sebuah lembaga ataupun perusahaan untuk dapat eksis di tengah ketatnya persaingan industri baik itu berbentuk produk ataupun jasa.

Menurut bahasa jemaah berasal dari bahasa arab yang memiliki arti berkumpul. Jemaah merupakan rombongan atau kumpulan orang yang melaksanakan ibadah. Dalam jemaah terdapat imam atau amir serta rukyah atau makmum, apabila ribuan orang melaksanakan salat di masjid namun tidak terdapat imam yang memimpin maka tidak dapat dikatakan salat berjemaah. Jemaah bukan hanya dalam keadaan ibadah salat, namun digunakan pula bagi 
orang-orang yang berkumpul untuk melaksanakan ibadah haji (jemaah haji). Menurut UU Nomor 8 Tahun 2019 pasal 4 menyebutkan bahwa Jemaah haji yaitu warga negara Indonesia yang beragama islam dan telah mendaftarkan diri untuk menunaikan ibadah haji dan telah memenuhi persyaratan. Jadi kualitas jemaah yang dibahas dalam penelitian ini yaitu mengenai terpenuhinya kebutuhan dan tercapainya tujuan pelanggan, yaitu jemaah dalam melaksanakan ibadah haji di tanah suci melalui segala tindakan manajemen strategik.

\section{HASIL DAN PEMBAHASAN}

Penelitian ini dilakukan di KBIH Masjid Raya Bandung yang merupakan lembaga bimbingan haji dan umrah di bawah naungan DKM Masjid Raya Bandung yang beralamat di Jl. Dalem Kaum No. 14 RT. 03, RW.01 Kel. Balonggede Kec. Regol Bandung, Jawa Barat. KBIH Masjid Raya Bandung telah mendapatkan izin operasional melalui Surat Keputusan (SK) Nomor: Mi14/1,Hj.09/1170/2002.

Susunan kepengurusan KBIH Masjid Raya Bandung telah diatur dalam Surat Keputusan DKM Masjid Raya Bandung dan diatur ulang sesuai dengan masa jabatan yang berlaku. Berdirinya KBIH Masjid Raya Bandung dilatar belakangi oleh kekhawatiran DKM Masjid Raya Bandung terhadap jemaah haji Indonesia yang terlihat tidak maksimal dan kurang siap dari segi keilmuannya ketika melaksanakan ibadah haji di tanah suci. Sebagian jemaah haji Indonesia cenderung mengikuti jemaah haji lainnya ketika melaksanakan syarat, rukun dan tata cara ibadah haji lainnya tanpa memahami esensi dari setiap hal dan gerakan yang dilakukan. KBIH ini memiliki lahan bagian dari Wakaf Masjid Raya Bandung dengan luas bangunan yaitu $5 \times 10 \mathrm{~m} 2$. Adapun status kepemilikannya yaitu tanah wakaf. Data ini belum di update kembali oleh pihak lembaga sehingga rincian aset KBIH Masjid Raya Bandung pada tahun 2019 belum dapat dilihat bagaimana perkembangannya.

Program kerja KBIH Masjid Raya Bandung terbagi menjadi dua, yaitu pra dan pasca pelaksanaan ibadah haji. Program pra-haji yaitu menyangkut Bimbingan Manasik Haji di Tanah air sampai di Tanah suci dan pasca pelaksanaan ibadah haji yaitu kegiatan di Majlis Taklim Jamiatul Hujaj. KBIH Masjid Raya Bandung memiliki visi yaitu: Terwujudnya kemandirian jemaah dalam melaksanakan Ibadah Haji dan Umrah sesuai sunnah Rasulullah SAW. dalam upaya meraih kemabruran di sisi Allah SWT. Adapun Misi KBIH yaitu; meningkatkan kualitas kehidupan beragama, memberikan pelayanan penyelenggaraan ibadah haji dan pembinaan kegiatan keislaman pasca ibadah haji, meningkatkan pelayanan bimbingan ibadah haji dan pembinaan kegiatan keislaman pasca ibadah haji, meningkatkan kualitas pelayanan bimbingan ibadah haji dengan memperoleh predikat mabrur/mabruroh dan terakhir memberikan bimbingan dan pelatihan manasik haji kepada jemaah calon haji sebelum dan 
selama menunaikan ibadah haji.

\section{Perumusan Strategi Bimbingan Manasik Haji dalam Meningkatkan Kualitas Jemaah}

Perumusan strategi meninjau terhadap hasil yang ingin dicapai dalam kurun waktu tertentu. Kegiatan dalam tahapan perumusan strategi dilakukan secara berkesinambungan, sistematis dengan memperhatikan beragam potensi juga kendala yang mungkin ada dalam berjalannya proses manajemen strategik. Ruang lingkup perumusan strategi dalam manajemen strategik berkaitan dengan pengembangan visi, misi, tujuan organisasi, identifikasi peluang dan ancaman eksternal organisasi, memastikan kekuatan dan kelemahan internal organisasi, dan pemilihan alternatif strategi yang di pilih dan digunakan oleh perusahaan.

KBIH memiliki visi yaitu untuk mewujudkan kemandirian jemaah dalam melaksanakan ibadah haji dan umrah untuk meraih kemabruran disisi Allah. Jadi dapat dikatakan bahwasannya visi KBIH Masjid Raya Bandung dimulai dari keinginan untuk mengadakan bimbingan, pembinaan dan pelayanan kepada jemaah yang baik untuk mendapatkan kualitas ibadah yang maksimal. Pelaksanaan ibadah haji merupakan ibadah yang kompleks, bukan hanya tentang fisik, materi, mental individu yang menjalankan tetapi juga melibatkan banyak pihak yang mendukung kelancaran proses ibadah haji baik akan, sedang dan setelah ibadah haji. Dengan beragamnya hal-hal yang harus dilakukan dalam pelaksanaan ibadah haji seperti menghafal doa-doa memahami syarat, rukun, wajib, sunnah haji, dsb. KBIH Masjid Raya Bandung mengupayakan agar para calon jemaah haji dapat memahami materi secara optimal demi terwujudnya kemandirian dalam melaksanakan ibadah haji di tanah suci.

KBIH Masjid Raya Bandung memiliki 5 misi yang harus dijalankan dan kelima hal tersebut saling berkaitan untuk memberikan pelayanan yang maksimal kepada para jemaah calon haji. David dalam Solihin (2012: 19) memaparkan bahwa salah satu komponen misi yang baik yaitu memiliki fokus terhadap kepentingan publik. Misi KBIH yang pertama yaitu "Meningkatkan Kualitas Kehidupan Beragama", hal ini menunjukan KBIH Masjid Raya Bandung memiliki kepedulian terhadap lingkungan dan yaitu mengenai kualitas jemaah dalam melaksankan ibadah haji. Misi-misi selanjutnya adalah hal-hal untuk memberikan pelayanan dan pembinaan yang optimal ketika pelaksanaan ibadah haji sampai berakhir masa ibadah haji.

Dalam wawancara bersama wakil pimpinan KBIH Yahya Ajlani (04 Juli 2019), menyampaikan bahwa para calon jemaah haji harus mendapatkan materi, praktik dan semua aspek yang terangkum dalam kegiatan bimbingan manasik haji untuk memenuhi kebetuhan jemaah selama melaksanakan rangkaian ibadah haji dan umrah di Tanah Suci selama 40 hari. Pembinaan pasca ibadah haji KBIH Masjid Raya Bandung mendirikan sebuah majlis taklim untuk menghimpun para 
alumni jemaah haji, wadah tersebut dinamakan dengan jamiatul bujaj. Adapun Kegiatan yang dilakukan berupa pengajian rutinan setiap bulan pada sabtu kedua mulai pukul 08.30 s/d 11.00 WIB. Jamiatul Hijaj dapat disebut himpunan alumni haji KBIH Masjid Raya Bandung yang memiliki struktur organisasi sendiri, yang bertujuan untuk menumbuhkan kembali semangatberibadah, mengikat silaturahmi antar alumni jemaah, dan untuk menjaga kemabruran haji dalam sudut pandang sosial.

Bimbingan manasik haji yang dilakukan KBIH Masjid Raya Bandung dimulai dengan pemberian teori mengenai ibadah haji maupun umrah, dari pengertian, hukum, syarat, rukun dan wajib haji. Pelaksanaan ibadah haji tidak hanya tentang haji saja tetapi juga menyangkut ibadah harian, seperti berjamaah ke masjid dsb. Adapun teori penunjang yang diberikan berupa doa harian. KBIH Masjid Raya Bandung menggunakan buku pedoman dari Kementrian Agama sebagai panduan bimbingan manasik haji, buku panduan tersebut berupa tuntunan manasik haji dan umrah, doa dan zikir manasik haji umrah, dan doadoa pilihan. Selain teori, bimbingan manasik haji ini tentunya identik dengan praktik. Praktik ibadah haji terbagi menjadi dua, yang pertama yaitu praktik ibadah yang dilakukan di $\mathrm{KBIH}$, dengan mempraktikan rukun ibadah haji dari mulai ihram sampai akhir secara tertib. Dan yang kedua yaitu praktik manasik haji massal (Se-Kota Bandung). Bimbingan manasik haji berlanjut sampai berada di tanah suci, para pembimbing bertanggung jawab memberikan pengarahan rutin kepada para jemaah untuk mengawasi kegiatan ibadah mereka, apakah telah memahami materi yang telah disampaikan di tanah air atau belum dan membantu jemaah lain yang kesulitan..

KBIH Masjid Raya Bandung sebagai suatu lembaga mendapatkan dukungan eksternal dari pemerintah berupa UUD dan kebijakan lainnnya mengenai penyelenggaraan ibadah haji selain itu dukungan dari masyarakat yaitu berupa kepercayaan untuk mendaftarkan diri di KBIH untuk mengikuti bimbingan manasik Di internal $\mathrm{KBIH}$ para pengurus disusun berdasarkan keahlian masing-masing. Begitupun pembimbing yang dipercaya untuk membimbing jemaah ke tanah suci merupakan seseorang yang telah mendapatkan legalitas dari Kementrian Agama melalui pelatihan sertifikasi pembimbing ibadah haji yang dilakukan Kanwil Kementrian Agama yang bekerja sama dengan UIN Sunan Gunung Djati Bandung.

\section{Pelaksanaan Strategi Bimbingan Manasik Haji dalam Meningkatkan Kualitas Jemaah}

Pelaksanaan strategi adalah fase manajemen startegis berupa pengelolaan bermacam-macam peralatan organisasi dan manajemen yang mengarahkan dan mengendalikan pemanfaatan sumber daya-sumber daya perusahaan (keuangan, manusia, peralatan dan lain-lain) melalui strategi yang telah dipilih. Pelaksanaan 
strategi merupakan tahapan kedua yang dilakukan dalam proses manajemen strategik. Segala aktivitas yang ada dalam perumusan strategi seperti visi, misi, tujuan, dan analisis lingkungan kemudian diterapkan dalam pelaksanaan strategi dengan bentuk program kerja, prosedur, dan pengorganisasian.

Program kerja merupakan rencana kegiatan yang dilakukan oleh perusahaan atau lembaga dalam waktu tertentu yang telah melalui tahapan tertentu sampai akhirnya program kerja tersebut terbentuk, adapun hasilnya diputuskan oleh kesepakatan antar anggota. Bimbingan manasik haji merupakan rencana kegiatan jangka panjang dengan waktu pelaksaannya dilakukan satu tahun sekali dalam kurun waktu kurang lebih delapan bulan sebelum musim haji dimulai. Bimsik dijadwalkan memiliki 25 kali pertemuan berupa teori dan praktik. (tidak disertai pembukaan dan pelepasan jemaah), lebih banyak dari ketentuan yang di anjurkan Kemenag yaitu sebanyak 15 kali, hal tersebut dikarenakan KBIH Masjid Raya Bandung memiliki visi untuk menjadikan jemaah haji yang mandiri dalam menjalankan ibadah haji. Menyadari terdapat beberapa hal penting dalam pelaksanaan ibadah haji untuk menjadikan jemaah yang berkualitas yang salah satunya yaitu dalam memaksimalkan materi dan praktik dalam bimbingan manasik haji, maka kegiatan bimbingan manasik haji pun di tambah menjadi 25 kali. KBIH salah satunya menggunakan buku pedoman yang diberikan Kementrian Agama untuk memberikan materi berupa ibadah harian seperti taharah, penjelasan macam-macam salat, baca quran, salat jenazah, pembahasan pokok mengenai haji dan umrah serta materi penunjang seperti ziarah, kesehatan, keselamatan penerbangan dan regulasi haji.

Endang Ma'sum selaku pimpinan KBIH dalam Wawancara pada tanggal 23 Desember 2018 mengatakan bahwa pemateri yang dipilih untuk menjalankan tugasnya merupakan orang-orang yang kompetem dibidangnya. Kementrian Agama dipilih untuk memberikan materi mengenai regulasi dan kebijakan pemerintah juga mengenai sosialiasi mengenai mekanisme pembuatan dokumen haji seperti, paspor, visa haji, dan dokumen administrasi (DAPIH). Kemudian pemberian materi mengenai pemeliharaan kesehatan dilakukan oleh Dinas Kesehatan Kota Bandung. Dinas kesehatan menjelaskan bagaimana cara mencegah penyakit tersebut, apa saja gejala terkena beat stroke, serta pertolongan pertama bagi jemaah haji yang terkena heat stroke. Selain itu Dinas Kesehatan juga menjelaskan mengenai antisipasi Mers-Cov yang merupakan penyakit sistem pernapasan yang disebabkan oleh virus corona atau virus unta.

Dua pembahasan tersebut juga terdapat di dalam buku tuntunan manasik haji dan umrah untuk dipahami lebih dalam lagi oleh para jemaah agar setidaknya jemaah bisa mencegah hal buruk terjadi. Selanjutnya pembahasan mengenai hukum-hukum dalam ibadah haji yang dijelaskan berupa pengertian Haji (Termasuk Pelaksanaan bagi Haji, Tamattu, Ifrad dan Qiran), hukum haji, waktu mengerjakan ibadah haji, hikmah miqat zamani dan miqat makani, syarat, rukun 
dan wajib haji, hikmah. Dalam segi fikih taharah, fikih salat dan masailul haji Pimpinan KBIH Endang Ma'sum memberikan pernyataan lebih lanjut bahwasannya yang dibahas dalam taharah yaitu:

“....Apa saja yang bisa digunakan untuk berwudhu, fardu wudhu serta dijelaskan pula mengenai hal-hal yang membatalkan wudhu, kemudian tentang salat dijelaskan tata cara salat jamak qashar, dan juga tata cara salat jenazah"(Wawancara pada tanggal 04 Juli 2019).

Dan yang terakhir yaitu praktik manasik haji yang dilakukan tiga kali yaitu di KBIH, Manasik Se-Kota Bandung dan praktik bersama. Penetapan durasi bimbingan manasik yang cukup banyak kiranya dapat membantu para jemaah calon haji dalam menunaikan ibadah hajinya untuk menjadi jemaah yang mandiri dan tercapainya tujuan manasik haji seperti diantaranya dapat menyebutkan syarat, rukun, wajib haji; melafadzkan niat ihram dan talbiah; mempraktikkan pelaksanaan tawaf, sai, melontar jumrah, dan tahallul.

Prosedur adalah aktivitas yang dilakukan secara khusus yang dijalankan secara terstruktur untuk menghasilkan hasil yang sama. Prosedur program bimbingan manasik haji dibagi dua. Yang pertama yaitu pendaftaran para calon jemaah haji untuk bimbingan di $\mathrm{KBIH}$, yang kedua prosedur pelaksanaan bimbingan manasik haji. Pendaftaran bimsik dimulai dengan menyertakan bukti setoran awal ke $\mathrm{KBIH}$, dan menyerahkan surat pernyataan memenuhi persyaratan pendaftaran haji yang telah diterbitkan oleh Kementrian Agama, terakhir membayar biaya bimbingan manasik haji. biaya pelaksanaan bimbingan yang besarannya sebagaimana yang ditetapkan oleh Direktur Jenderal Penyelenggaraan Haji dan Umrah No: D/799 Tahun 2013 Bab V Pasal (ayat (4) paling banyak Rp 3.500.000,- (Tiga juta lima ratus ribu rupiah).

Setelah mengikuti prosedur pendaftaran dan membayar rincian biaya manasik haji, barulah para calon jemaah haji mendapatkan panggilan untuk mengikuti bimbingan manasik di KBIH Masjid Raya Bandung mengikuti jadwal kegiatan yang telah ditetapkan dam materi-materi yang diterangkan dalam jadwal kegiatan membahas taharah atau bersuci, salat, ziarah, dan materi haji secara khusus sebagaimana yang telah dijelaskan dalam materi program kerja diatas. Mengenai HajiTamattu termasuk ke dalam pelaksanaan bimbingan manasik haji dengan melaksanakan haji umrah terlebih dahulu, baru mengerjakan haji. Pimpinan KBIH Masjid Raya Bandung juga menjelaskan dalam menyampaikan materi menggunakan metode ceramah, tanya jawab, visualisasi, praktik, diskusi, batsul masa'il, dan diusahakan komunikasi dua arah. Biasanya teori diberikan 1/4 jam kemudian sisa waktunya digunakan untuk tanya jawab. Hal ini dilakukan karena dirasa efektif dalam memberikan materi secara maksimal agar harapan menjadikan jemaah haji yang mandiri serta berkualitas dapat tercapai.

KBIH Masjid Raya Bandung melakukan praktik bimbingan manasik haji secara bertahap dalam beberapa kali pertemuan sesuai dengan jadwal kegiatan 
yang telah disusun. Hal ini dilakukan karena disesuaikan dengan keadaan jemaah yang sebagian besar telah berusia lanjut dan tidak memungkinkan untuk melaksanakan materi dan praktik sekaligus dalam satu hari.Berdasarkan penelusuran dari dokumen tertulis (tidak diterbitkan; 04 Juli 2019) KBIH Masjid Raya Bandung,waktu bimbingan manasik haji pada saat di tanah air dilakukan 25 kali pertemuan setiap hari minggu dengan durasi waktu 2 (dua) jam 30 menit sampai dengan 3 (tiga) jam setiap pertemuannya dimulai pukul $08.30 \mathrm{~s} / \mathrm{d} 11.00$ WIB dari mulai tanggal 10 Desember 2018 sampai dengan 03 Juni 2019. Dan pelaksanaan bimbingan di Madinah Al-Munawarah pada hari kamis tanggal 19 Juli 2018, dan di Makkah Al-Mukaramah pada tanggal 27 Juli 2018 (Pra Haji). Bimbingan Manasik Haji yang dilaksanakan di Masjid Raya Bandung Provinsi Jawa Barat bertempat di ruang utama atau di dalam Masjid dengan keadaan beralaskan karpet salat. Untuk kondisi tersebut sudah lebih cukup memadai dijadikan tempat bimbingan manasik, karena luasnya ruangan bisa menampung ratusan orang.

Adapun tipologi struktur organisasi yang digunakan oleh KBIH Masjid Raya Bandung yaitu organisasi lini, dilihat dari sistem di KBIH Masjid Raya Bandung yang sederhana dan tujuan $\mathrm{KBIH}$ yang tidak terlalu rumit, misi yang sederhana, dan sasarannya yang mudah ditetapkan yaitu untuk menjadikan jemaah yang mandiri dalam melaksanakan ibadah haji. Berdasarkan wawancara bersama Pimpinan KBIH Masjid Raya Bandung Endang Ma'sum (23 Desember 2018) bahwa KBIH memiliki struktur organisasi beranggotakan sembilan orang yang telah di pilih dan ditempatkan berdasarkan keahlian anggotanya masingmasing. penyusunan struktur organisasi di KBIH Masjid Raya Bandung dilakukan secara efektif dengan mengurangi jumlah pengurus yang dianggap tidak efisien. KBIH Masjid Raya Bandung berada di bawah naungan DKM Masjid Raya Bandung maka pelindung yang memiliki tugas dan wewenang untuk melindungi dan membina KBIH yaitu, Kepala Badan Pengelola Islamic Centre (BPIC) dan Ketua DKM Masjid Raya Bandung. Adapun penasihat yang memiliki tugas dan wewenang untuk membina dan membimbing pimpinan Kelompok Bimbingan Ibadah haji (KBIH). Adapun struktur kepengurusannya yaitu, ketua, wakil ketua, sekretaris, wakil sekretaris, bendahara, bidang TU dan kesekretariatan, bidang pembelajaran dan bimbingan, bidang informasi dan pubkomdok, dan bidang peralatan, inventaris dan kebersihan.

Para pengurus yang terdaftar di KBIH Masjid Raya Bandung juga memiliki tugas sebagai pembimbing manasik haji bagi para jemaah. pembimbing yang menyampaikan materi baik teori ataupun praktik, merupakan pengurus KBIH ataupun diluar jajaran pengurus yang merupakan orang-orang yang mumpuni di bidangnya. Selanjutnya pembimbing yang terpilih melakukan bimbingan jemaah calon haji ke tanah suci yaitu seseorang yang telah mendapatkan sertifikasi pembimbing haji dari Kementrian Agama dengan mengikuti prosedur Pretest dan 
Post-test. Prosedur untuk menentukan pembimbing tergantung KBIH masingmasing. Pengurus yang menjadi pembimbing setor awalnya minimal sudah tiga tahun. Hal tersebut bisa dikatakan sebagai salah satu kemudahan yang diberikan oleh Kementrian Agama yang memberikan tenggang waktu lebih sebentar.

\section{Evaluasi Strategi Bimbingan Manasik Haji dalam Meningkatkan Kualitas Jemaah}

Evaluasi startegi dijelaskan Dalam Wahyudi (1996:139), adalah proses untuk mendapatkan informasi mengenai rencana-rencana bisnis dan kemampuannya untuk dilakukan perbandingan apakah informasi itu telah sesuai dengan standar yang telah ditentukan atau tidak.Evaluasi strategi merupakan tahapan untuk mengananalisis sesuatu yang kurang dan salah dalam kegiatan manajemen strategik untuk diperbaiki di masa yang akan datang dan menjadi referensi untuk melakukan strategi yang lebih baik lagi. Selain evaluasi strategi juga terdapat kontrol strategi, yang merupakan tindakan untuk memperbaiki kondisi yang berubah, dengan melakukan penyesuaian agar aktivitas manajemen strategik tetap stabil.

Berdasarkan hasil wawancara dan observasi di lapangan bersama Wakil Pimpinan KBIH Masjid Raya Bandung Yahya Ajlani bahwasannya terdapat beberapa hal yang perlu di evaluasi dalam bimbingan manasik haji di KBIH yaitu: Tidak sedikit jemaah yang telah lanjut usia, pendidikan yang variatif, sehingga perlu kesabaran dalam memberikan materi, jemaah rata-rata sibuk, tidak semua mengikuti dari awal, terkadang ketika berangkat dia tidak memiliki pemahaman yang kuat (Wawancara pada tanggal 04 Juli 2019).

Proses evaluasi KBIH Masjid Raya Bandung dapat dibedakan menjadi dua, yaitu evaluasi yang dilakukan dalam jangka pendek dan jangka panjang. Evaluasi jangka pendek bisa dilihat dari kegiatan evaluasi yang sifatnya momentum yaitu dilakukan setiap ada kesempatan setelah kegiatan. Dan jangka panjang yaitu kegiatan evaluasi yang dilakukan setelah pelaksanaan bimbingan manasik haji usai dalam satu musim haji atau dapat dikatakan evaluasi tahunan. Kegiatan evaluasi dan pengawasan secara formal dilakukan dengan kegiatan rapat antar pengurus KBIH Masjid Raya Bandung, DKM Masjid Raya Bandung dan komponen-komponen yang terlibat dalam kegiatan bimbingan manasik haji.

Hal utama yang di evaluasi biasanya yaitu jemaah dan pemberian materi dalam bimbingan manasik haji. Karena tidak sedikit jemaah calon haji yang telah berumur sehingga materi harus diberikan secara berulang-ulang dan cukup memakan waktu. Selain itu jemaah hajimemiliki latar pendidikan yang berbedabeda dilihat dari latar pendidikan terakhir jemaah maka materi disesuaikan dan pemberian materi dilakukan sesederhana mungkin. Bagi jemaah yang tidak mengikuti bimbingan manasik haji secara keseluruhan, maka solusi yang dilakukan oleh $\mathrm{KBIH}$ yaitu dengan bmbingan intensif, terutama menjelang 
pelaksanaan ibadah haji.

Berdasarkan hasil wawancara yang dilakukan bersama Wakil Pimpinan KBIH Masjid Raya Bandung mengenai program manasik haji bahwa Sudah sesuai dari sudut penyelenggaraan. Dari segi bimsik berhasil sedangkan dari output kembali kepada diri jemaah masing-masing (Wawancara pada tanggal 04 Juli 2019). Salah satu bentuk keberhasilan yang didapatkan oleh KBIH Masjid Raya Bandung secara umum yaitu telah terakreditasi A pada tahun 2017. Secara spesifik yaitu dapat melaksanakan program bimbingan manasik haji dan mampu membimbing jemaah dari tahun ke tahunnya.

\section{PENUTUP}

Tahapan-tahapan manajemen strategik yang berupa perumusan strategi, pelaksanaan strategi dan evaluasi strategi memiliki hubungan satu sama lain. Dalam perumusan strategi terdapat tiga unsur yang dijalankan KBIH Masjid Raya Bandung yaitu pengembangan visi, misi dan tujuan, analisis lingkungan dan alternatif strategi. Perumusan strategi dilakukan melalui pengembangan visi dan misi $\mathrm{KBH}$ dalam memaksimalkan pelayanan $\mathrm{KBIH}$ dan program Bimbingan Manasik Haji dengan pembekalan materi dan praktik yang optimal untuk menjadikan jemaah haji yang mandiri dan berkualitas (mabrur). KBIH Masjid Raya Bandung melakukan bimbingan manasik haji selama di tanah air selama 25 kali pertemuan dan dilanjutkan di tanah suci, sampai kembali lagi ke Indonesia dihimpun dalam alumni jemaah haji Jamiatul Hujaj.

Pelaksanaan strategi berkaitan dengan program kerja KBIH dalam hal ini berfokus pada program Bimbingan Manasik haji, prosedur, dan yang terakhir yaitu pengorganisasian di KBIH Masjid Raya Bandung. Program kerja bimbingan manasik haji di KBIH Masjid Raya Bandung dilakukan melaui prosedur pendaftaran terlebih dahulu dengan mengikuti ketentuan untuk membayar biaya bimbingan Rp 3.500.000,- (tiga juta lima ratus ribu rupiah) denganmenyertakan syarat-syarat pendaftaran bimbingan manasik haji. Setelah proses pendaftaran barulah para jemaah calon haji dipanggil untuk mengikuti pelaksanaan kegiatan bimbingan manasik haji. Adapun materi disampaikan oleh orang-orang yang dipercaya mampu dalam bidanngya, seperti materi mengenai kebijakan-kebijakanhaji dan kebijakan pemerintah lainnya diberikan oleh Kementrian Agama, Dinas Kesehatan mengenai kesehatan dan pembahasan ibadah haji, ilmu penunjang serta hukum fikih lainnya dilakukan oleh orangorang dan pembimbing yang dipercaya mampu dalam menyampaikan teori dan praktek mengenai ibadah haji dengan maksimal.

Bimbingan Manasik di tanah air dilakukan selama 25 kali pertemuan dengan memadatkan pembekalan materi (teori dan praktik) mengikuti jadwal yang telah ditetapkan, yaitu setiap hari minggu dimulai pukul $08.30 \mathrm{~s} / \mathrm{d} .11 .00$. Kegiatan bimbingan manasik haji di KBIH Masjid Raya Bandung dikelola oleh para 
pengurus yang telah di tempatkan sesuai bidangnya masing-masing. Adapun pengurus KBIH yang dipercaya membimbing jemaah di tanah suci yaitu mereka yang telah mendapatkan sertifikat dari Kementrian Agama. Pelaksanaan bimbingan dilakukan juga ketika di Madinah dan di Makkah sesuai dengan jadwal yang telah di tetapkan oleh panitia.

Tahap evaluasi merupakan tahapan terkahir dalam proses manajemen startegi untuk mengetahui apakah program bimbingan manasik haji telah dilaksanakan dengan baik atau masih ada kekurangan yang perlu diperbaiki. Evaluasi strategi yang dilakukan oleh KBIH Masjid Raya Bandung terbagi menjadi dua, yaitu yang bersifat jangka panjang dan jangka pendek. Evaluasi yang sifatnya jangka panjang dilakukan ketika musim haji selesai, melalui rapat tahunan antar pengurus $\mathrm{KBIH}$, DKM Masjid Raya Bandung, dan komponen-komponen yang bersangkutan. Adapun yang bersifat jangka pendek yaitu evaluasi yang dilakukan setiap kegiatan bimbingan manasik haji selesai, dan dilakukan ketika ada kesempatan untuk memberikan pengarahan/briefing.

KBIH Masjid Raya Bandung dalam kinerja dan aktivitasnya telah menerapkan konsep Manajemen Strategikdan secara implikasi teoritiknya Manajemen Strategik Bimbingan Manasik Haji yang diperuntukan untuk lembaga yang berorientasi pada keuntungan material saja, ternyata dalam kenyataannya dapat diimplementasikan dalam sebuah program kerja KBIH Masjid Raya Bandung melalui Program Bimbingan Manasik Haji. Ketika manajemen strategik diterapkan dalam program kerja baik disengaja ataupun tidak, seperti yang ditunjukan dalam hasil penelitian, KBIH Masjid Raya Bandung memiliki keumungkinan yang besar untuk bisa bertahan hidup dan mampu melayani jemaah calon haji dengan sangat baik dalam beberapa tahun ke depan.

\section{DAFTAR PUSTAKA}

Amir, M. T. (2011). Manajemen Strategik-Konsep dan Aplikasi. Jakarta: PT Rajagrafindo Persada.

Dirjen Penyelenggaraan Ibadah Haji dan Umrah. (2017). Modul III dan IV, Kebijakan Penyelenggaraan Ibadab Haji. Jakarta: Kementrian Agama RI.

Dirjen Penyelenggaraan Ibadah Haji dan Umrah. (2017). Modul V, Bimbingan Manasik Haji dan Umrah. Jakarta: Kementrian Agama RI.

Hartono, J. (2005). Sistem Informasi Strategik. Yogyakarta: CV ANDI OFFSET. Kadmasasmita, A. D. (2005). Manajemen Strategis - Konsep dan Aplikasi. Bandung:

Lembaga Administrasi Negara RI Pusat Kajian dan Diklat Aparatur I.

Mulyadi, (1993). Sistem Akuntansi. Yogyakarta: STIE YKPN.

Nawawi, H. (2005). Manajemen Startegik. Yogyakarta: Gadja Mada University

Press.

Nazir, M. (2011). Metode Peneliian. Bogor: Ghalia Indonesia.

Siagian, S. P. (2000). Manajemen Stratejik. Jakarta: PT Bumi Aksara. 
Siswanto, J. (2006). Prosesi Mas Joko Pergi Haji. Yayasan Bakti Nusantara, Pusat Kajian Kebijakan dan Pendidikan Politik.

Solihin, I. (2012). Manajemen Strategik. Bandung: Penerbit Erlangga.

Sukayat, T. (2016). Manajemen Haji Umroh dan Wisata Agama. Bandung: Simbiosa Rekatama Media.

Taufiqurokhman, (2016). Manajemen Strategik. Jakarta Pusat: FISIP Universitas Prof. Dr. Moestopo Beragama.

Taufiqurrochman, (2011). Manasik Haji dan Ziarah Spiritual. Malang: UINMALIKI PRESS.

Terry, G. R., \& Rue, L. W. (2000). Dasar-dasar Manajemen. Jakarta: PT Bumi Aksara.

Wahyudi, A. S. (1996). Manajemen Strategik - Pengantar Proses Berpikir Strategik. Jakarta Barat: Binarupa Aksara.

\section{Sumber Internet}

Prastito, Agung. 2015. Analisis Pengarub Kualitas pelyanan, Harga dan Fasilitas Terbadap Kepuasan Konsumen Pada Pandawa Water Word Solo Baru, diakses 1 Juli 2019 dari https:/ / eprints.ums.ac.id 
Ni'mah Nurfadillah, A.S, Herman 